Сидор Галина, Савків Уляна, Андрусів Уляна. Митний простір України: проблемні аспекти та прагматизм їхнього вирішення. Економічний дискурс. 2021. Випуск 1-2. С. 40-46.

DOI: https://doi.org/10.36742/2410-0919-2021-1-4

\title{
Удк 330.322
}

\section{JEL Classification P47}

\section{Сидор Галина}

к. е. н., доцент, доцент кафедри фундаментальних та спеціальних дисциплін Чортківський навчально-науковий інститут підприємництва і бізнесу

Західноукраїнського національного університету

м. Чортків, Україна

E-mail: sidor.gal@ukr.net

ORCID: 0000-0001-9578-0588

\section{Савків Уляна}

к. е. н., доцент, доцент кафедри обліку і оподаткування

ДВНЗ «Прикарпатський національний університет ім. Василя Стефраника»

м. Івано-Франківськ, Україна

E-mail: usavkiv@meta.ua

ORCID: 0000-0002-1101-4702

\section{Андрусів Уляна}

к. е. н., доцент, доцент кафедри теорії економіки та управління Івано-Франківський національний технічний університет нафти і газу

м. Івано-Франківськ, Україна

E-mail: andrusivu@ukr.net

ORCID: 0000-0003-1793-0936

\section{МИТНИЙ ПРОСТІР УКРАЇНИ: ПРОБЛЕМНІ АСПЕКТИ ТА ПРАГМАТИЗМ ÏХНЬОГО ВИРІШЕННЯ}

\section{Анотація}

Bступ. Необхідність пошуку теоретичних і практичних шляхів вирішення проблемних аспектів формування митного простору України в умовах здійснення соціально-економічних перетворень набуває вагомого значення. 3 огляду на політичну та економічну ситуацію в нашій країні важливою складовою здійснення ефеективної митної політики має бути визначення ії напрямів на основі засад зовнішньоекономічної діяльності, пріоритетів стратегії економічного розвитку держави.

Meтоди. У процесі написання статті використано загальнонаукові прийоми й методи економічних досліджень. Теоретико-методологічну основу розвідки становлять аналіз наукових праць вітчизняних та зарубіжних науковців із питань вивчення проблемних аспектів митного простору України, ресурси Internet. У статті використано загальні та спеціальні методи дослідження, зокрема: загальнонаукові та спеціальні - для забезпечення досягнення цієї мети; абстрактно-логічний та діалектичний методи аналізу - для обгрунтування теоретичних положень та висновків. Застосовано прийоми графічного відображення результатів.

Результати. У статті систематизовано проблемні аспекти формування митного простору України та ссрормульовано рекомендації щодо прагматизму їхнього вирішення в сучасних умовах. Акцентовано увагу на необхідності посилення співпраці правоохоронних і митних органів з метою зменшення ризиковості митного простору України. Запропоновано посадовим особам митних служб проходити спеціалізовану підготовку та перепідготовку, яку проводить Департамент спеціалізованої підготовки та кінологічного забезпечення, оскільки в період глобальних трансформацій світова економіка ставить нові вимоги для тих інституцій, працівники яких 
відповідають за безпеку митного простору країни. Окреслено наслідки проблемних аспектів формування митного простору України.

Перспективи. Подальші наукові дослідження спрямуємо на вивчення стану просторової асиметрії митного простору України в контексті визначення можливостей і перспектив його збалансування та підвищення результативності.

Ключові слова: митний простір, митне середовище, митний клімат, митна політика, контрабанда, порушення митних правил.

\section{Вступ.}

Проблемними аспектами формування митного простору України є широкий спектр питань: від модернізації інформаційного забезпечення до налагодження тісної співпраці 3 іншими державами, викорінення корупційної складової під час проходження прикордонного та митного оформлення тощо.

Необхідність пошуку теоретичних і практичних шляхів вирішення проблемних аспектів формування митного простору України в умовах здійснення соціально-економічних перетворень набуває вагомого значення. 3 огляду на політичну та економічну ситуацію в нашій країні важливою складовою здійснення ефективної митної політики має бути визначення її напрямів на основі засад зовнішньоекономічної діяльності, пріоритетів стратегії економічного розвитку держави.

\section{Аналіз останніх досліджень та публікацій.}

Дослідження проблем формування митного простору України сьогодні набуває особливої актуальності. Теоретичні й практичні аспекти формування митного простору розглянули в своїх працях провідні вітчизняні й зарубіжні дослідники, серед них: І. О. Іващук [1], В. В. Столін [9] та ін. Крім вищевказаних наукових розробок, варто назвати й дослідження автора роботи - Г. В. Сидор [3-8].

Однак багато проблем теоретичного та практичного характеру у цій сфері все ще не вивчено, що зумовлює потребу в проведенні додаткових наукових пошуків щодо прагматизму вирішення проблемних питань формування митного простору України.

\section{Мета.}

Систематизувати проблемні аспекти формування митного простору України та сформулювати рекомендації щодо прагматизму їхнього вирішення в сучасних умовах.

\section{Методологія дослідження.}

У процесі написання статті використано загальнонаукові прийоми й методи економічних досліджень. Теоретико-методологічну основу розвідки становить аналіз наукових праць вітчизняних та зарубіжних науковців із питань вивчення проблемних аспектів митного простору України, ресурси Internet. У статті використано загальні та спеціальні методи дослідження, зокрема: загальнонаукові та спеціальні - для забезпечення досягнення цієї мети; абстрактно-логічний та діалектичний методи аналізу - для обгрунтування теоретичних положень та висновків. Застосовано прийоми графічного відображення результатів.

\section{Результати.}

У рамках дослідження визначено проблемні аспекти економічної інтеграції країн, що створюють перешкоди збалансуванню митного простору, а саме:

- зростання нестабільності та посилення кризових явищ у світі, що не дають можливості об'єктивно спрогнозувати розвиток торгівлі та міжнародної економіки. Однак за правильно визначеної стратегії, з нашої точки зору, можливо протистояти викликам, забезпечивши сприятливі та взаємовигідні умови у торгівлі;

- лобіювання у процесі глобальної інтеграції економічно розвиненими країнами власних 
інтересів;

- загострення питань національної, в тому числі економічної безпеки;

- відсутність у країнах, що розвиваються, стійких структурних реформ;

- низький рівень економічного інтересу між країнами або надмірна торговельна взаємозалежність країн тощо.

Проведене дослідження підтверджує важливість процесів інтеграції для збалансування митного простору.

3 нашої точки зору, неспроможність держав виробити механізми для боротьби та протистояння геополітичним загрозам, а також порушення взаємних зобов'язань між громадянами й країнами та низький рівень довіри до держави як інституту є одним із проблемних аспектів формування митного простору. Серед дестимулюючих фракторів варто назвати корупційну складову в органах державного управління, зловживання повноваженнями (поширення практики використання службового становища та влади в своїх цілях). Такі проблемні аспекти є типовими для країн із затяжними трансформаційними процесами, і їхнє зростання, з нашого погляду, - це тривожний сигнал щодо наростання недовіри громадян до держави як інституту.

Серед проблемних аспектів формування митного простору України, на нашу думку, варто виокремити зростання впливу високоорганізованих злочинних угрупувань, які за наслідками та масштабністю набули глобальних обсягів. Пропонуємо виокремити дві критичні, найбільш основні, проблеми в результаті діяльності міжнародної злочинності: їхнє зрощення, тобто співпраця із державними органами влади та залучення до фінансування терористичних організацій, що є критичним для світового управління.

Проблеми порушення митних правил все ще не вирішені, незважаючи на спільні зусилля та ініціативи урядів країн та міжнародних організацій. Порушення правил переміщення через митний кордон на практиці загрожують національній безпеці та економіці держави, створюють негативний імідж для неї.

У сучасних умовах для України порушення митних правил набуває значного поширення i негативно впливає на авторитет держави у світі загалом та на економічну ситуацію в країні, зокрема. Цей вид злочинності є особливим, тому для того, щоб його подолати, необхідно постійно вдосконалювати систему протидії.

Протидіяти порушенню митних правил потрібно через здійснення результативної профілактики, зокрема через застереження членів суспільства від вчинення митних правопорушень. Отже, одним із важливих завдань митних органів держави є профілактика митних правопорушень. Водночас протидіяти порушенню митних правил необхідно через міжнародне співробітництво, яке відіграє вагому роль у процесі попередження і боротьби із митними правопорушеннями. Міжнародне співробітництво передбачає обмін досвідом; обмін способами та формами здійснення транскордонного спостереження; інформацією та даними щодо організованих злочинних угрупувань, які діють на території інших держав; діяльності працівників поліції під прикриттям, а також охорони свідків тощо.

Проблемним аспектом формування митного простору України, на нашу думку, $€$ невизначеність (наприклад, цілей, ділового клімату в країні, інформації, національного та міжнародного законодавчого поля тощо).

Серед проблемних сторін формування митного простору України, на нашу думку, варто назвати корупційну складову та тіньову економіку, які під впливом економічної лібералізації та глобалізаційних процесів отримали нову хвилю розвитку. Для економічного розвитку України ці складові все ще є одними із найбільш загрозливих. Так, у 2018 р. рівень тінізації економіки країни становив 47,2\% від обсягів офріційного валового внутрішнього продукту. Україна за індексом сприйняття корупції посідала 120 місце із 180 країн з показником 32.

Проведене дослідження дало можливість виокремити ще одну проблемну складову формування митного простору України, а саме: фуунцціонування нерезультативної системи 
управління ризиками у процесі здійснення митного оформлення та митного контролю. 3 нашої точки зору, вона не здатна функціонувати без врегулювання процесів обміну інформацією, практичної реалізації та фрормування заходів щодо оцінювання майбутніх ризиків. Це проблема, яка виходить за межі вітчизняного кордону, тому потребує колективного вирішення.

На теоретичному рівні проблему становлять наявність розбіжностей статистичних даних, зокрема виявляється їхня невідповідність у процесі проведення перевірки достовірності подання інформації суб'єктами зовнішньоекономічної діяльності. Статистична інформація, що подається на митницю країни-експортера (імпортера) та українську митницю, доволі часто не збігається, що збільшує (зменшує) базу оподаткування. Виявлена різниця / похибка становить потенційний обсяг зловживань. Тому акцентуємо увагу на необхідності посилення співпраці правоохоронних і митних органів з метою зменшення кількості порушень митного простору України.

Дедалі більшого значення у сучасних умовах розвитку України набуває вирішення проблемних питань професійної підготовки фахівців з митної справи та удосконалення їхніх умінь та навичок, які необхідні для подальшої роботи у митних органах. У період глобальних трансформацій світова економіка ставить нові вимоги для тих інституцій, працівники яких відповідають за безпеку митного простору країни.

3 нашої точки зору, фахівцям інституцій, працівники яких гарантують безпеку митного простору України, для результативного виконання їхніх функцій, обов'язків та завдань недостатньо тих вмінь та навичок, які вони отримали після завершення навчання в освітньому закладі. 3 огляду на це пропонуємо посадовим особам митних служб проходити спеціалізовану підготовку та передпідготовку, яку проводить Департамент спеціалізованої підготовки та кінологічного забезпечення.

На базі Департаменту спеціалізованої підготовки та кінологічного забезпечення за станом на 01.01.2018 р. спеціалізовану підготовку пройшли 2829 осіб (150 груп ), з них:

- за очною формою навчання - 1036 посадових осіб;

- за очно-дистанційною формою навчання - 1145 посадових осіб;

- за дистанційною формою навчання - 648 посадових осіб.

Динаміка кількості осіб, які пройшли спеціальну та спеціалізовану підготовку на базі Департаменту спеціалізованої підготовки та кінологічного забезпечення, відображена на рис. 1.

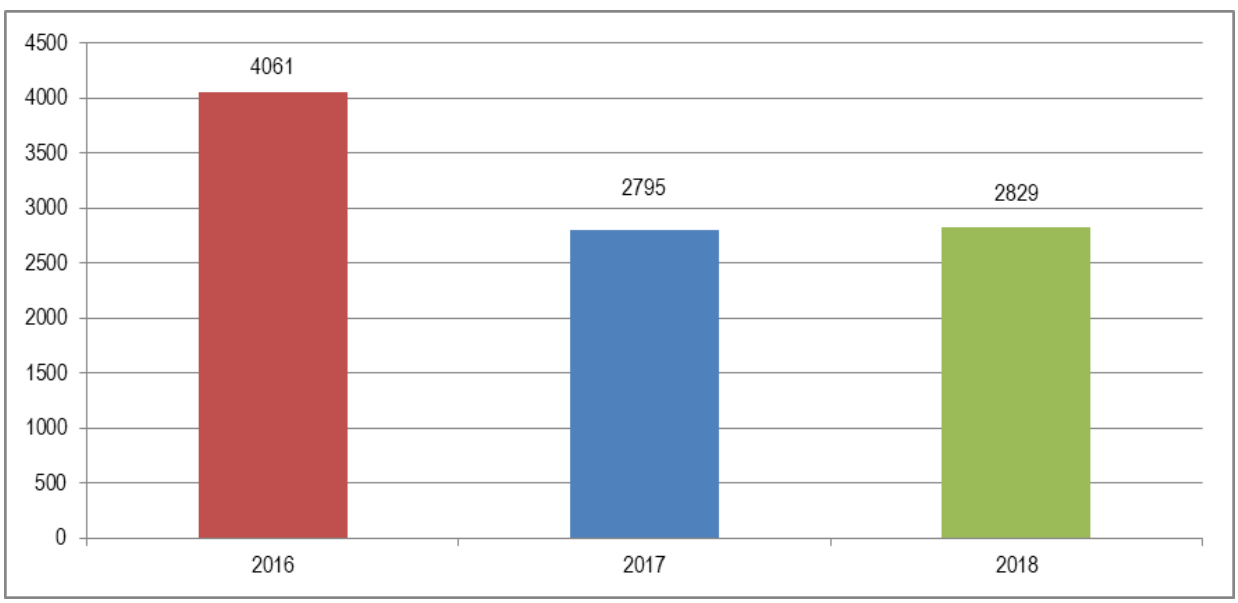

Рис. 1. Динаміка кількості осіб, які пройшли спеціальну та спеціалізовану підготовку на базі Департаменту спеціалізованої підготовки та кінологічного забезпечення протягом 2016-2018 pp.*

*Джерело: складено на основі [2] 
Проблемні аспекти формування митного простору України та їхні характерні ознаки наведено у табл. 1.

Таблиця 1. Проблемні аспекти формування митного простору України та їхні характерні ознаки*

\begin{tabular}{|c|c|}
\hline Проблемні аспекти & Характеристика \\
\hline Процеси дефляції у великих економіках & $\begin{array}{c}\text { затяжна ледве не нульова інфрляція або дефлляція у регіоні чи великій } \\
\text { економіці }\end{array}$ \\
\hline Бульбашки активів у великих економіках & $\begin{array}{c}\text { нераціонально завищена вартість активів, таких як акції, сировинні товари, } \\
\text { житло та ін. у регіоні та великих економіках }\end{array}$ \\
\hline $\begin{array}{l}\text { Дефолт фінансової установи або великого } \\
\text { фінансового механізму }\end{array}$ & $\begin{array}{c}\text { крах фінансової установи або неправильне функціонування фінансової } \\
\text { системи, яке впливає на міжнародну економіку }\end{array}$ \\
\hline Фіскальна криза в ключових економіках & $\begin{array}{c}\text { тягар надмірної заборгованості, який породжує кризи ліквідності або } \\
\text { суверенні боргові кризи }\end{array}$ \\
\hline $\begin{array}{l}\text { Високий рівень безробіття або неповна } \\
\text { зайнятість }\end{array}$ & $\begin{array}{c}\text { стабільно високий рівень структурного безробіття або недовикористання } \\
\text { можливостей працездатного населення }\end{array}$ \\
\hline Незаконна торгівля & широкомасштабна діяльність поза рамками законодавчого поля \\
\hline Шокові ціни на енергоносії & суттєве зростання або зниження цін на енергоносії \\
\hline Некерована інфляцція & некероване зростання рівня цін на послуги та товари у ключових економіках \\
\hline
\end{tabular}

Розглянувши проблемні сторони формування митного простору, відображені у табл. 1, зазначимо, що основними наслідками таких проблем є:

- кризові явища в ключових сферах економіки;

- зростання боргових зобов'язань держави;

- збільшення боргового навантаження на економіку;

- підвищення рівня інфляції тощо.

\section{Висновки і перспективи.}

У рамках дослідження встановлено, що сьогодні наша країна має розробити та впровадити зовнішньоекономічну стратегію, яка має бути спрямована на стабілізацію макроекономічної ситуації в державі, врахування викликів глобального середовища, досягнення цілей сталого розвитку, збалансування митного простору України.

Подальші наукові дослідження спрямуємо на вивчення стану просторової асиметрії митного простору України в контексті визначення можливостей і перспектив його збалансування та підвищення результативності.

\section{Список використаних джерел}

1. Іващук І. О. Оцінка активності країн у митному просторі та ії вплив на формування митного середовища. Наукові записки Національного університету «Острозька академія». Серія : Економіка. 2009. Вип. 11. С. 40-57. 26.03.2021).

2. Сайт Державної служби статистики України. URL: http://www.ukrstat.gov.ua. (дата звернення:

3. Сидор Г. В., Кульчицька С. М. Митний простір: сучасна інтерпретація. Економіко-управлінські аспекти трансформації та інноваційного розвитку галузевих і регіональних суспільних систем в сучасних умовах : Всеукр. наук.-практ. інтернет-конф., 11-12 квіт. 2019 р.: матер. / Івано-Франківськ, 2019. С. 264-266.

4. Сидор Г. В., Кульчицька С. М. Митний простір України в умовах глобалізації. Актуальні проблеми соціально-економічних систем в умовах трансформаційної економіки : V Всеукр. наук.-практ. конфр., 11-12 квіт. 2019 р. : зб. наук. статей за матер у 2-х ч. / НМетАУ. Дніпро, 2019. Ч. 1. С. 106-108. URL: https://nmetau.edu.ua/ua/mdiv/i2015/p2685._(дата звернення: 26.03.2021).

5. Сидор Г. В. Оцінювання активності країн у митному просторі. Модернізація економіки України: основні тенденції та проблеми : колективна монографрія / за ред. канд. екон. наук, доц. Кульчицької Н. Є. Чортків : ТНЕУ, 2020. С. 202-210.

6. Сидор Г. В., Андрусів У. Я., Вербіцька І. І. Стан просторової асиметрії митного простору в Україні. 
Науковий вісник ІФНТУНГ. Серія : «Економіка та управління в нафртовій і газовій промисловості». 2020. №2 (22). C. 173-180.

7. Сидор Г. В., Андрусів У. Я., Вербіцька І. І. Стратегічні вектори розвитку митного простору України в глобальному середовищі. Науковий вісник ІФНТУНГ. Серія : «Економіка та управління в нафртовій $і$ газовій промисловості». 2020. № 1 (21). С. 27-34.

8. Сидор Г. В. Теоретичні аспекти становлення митного простору. Модернізація економіки: сучасні реалії, прогнозні сценарії та перспективи розвитку : Міжнар. наук.-практ. конф., 28 квіт. 2020 р. : матер. I Херсон, 2020. С. 563-565.

9. Столин В. В. Сомосознание личности. Москва : Издательство Московского университета, 1983.

Статтю отримано: 28.03.2021 / Рецензування 03.05.2021 / Прийнято до друку: 20.06.2021

\author{
Halyna Sydor \\ Ph.D. (in Economics), Associate Professor \\ Department of Fundamental and Specialized Disciplines \\ Chortkiv Education and Research Institute of Enterpreneurship and Business \\ West Ukrainian National University \\ Chortkiv, Ukraine \\ E-mail: sidor.gal@ukr.net \\ ORCID: 0000-0001-9578-0588 \\ Uliana Savkiv \\ Ph.D. (in Economics), Associate Professor \\ Department of Accounting and Auditing \\ Vasyl Stefanyk Precarpathian National University \\ Ivano-Frankivsk, Ukraine \\ E-mail: usavkiv@meta.ua \\ ORCID: 0000-0002-1101-4702 \\ Uliana Andrusiv \\ Ph.D. (in Economics), Associate Professor \\ Department of Theory of Economics and Management \\ Ivano-Frankivsk National Technical University Oil and Gas \\ Ivano-Frankivsk, Ukraine \\ E-mail: andrusivu@ukr.net \\ ORCID: 0000-0003-1793-0936
}

\title{
CUSTOMS SPACE OF UKRAINE: PROBLEM ASPECTS AND PRAGMATISM OF THEIR SOLUTION
}

\begin{abstract}
Introduction. The need to find theoretical and practical ways to solve the problematic aspects of the formation of the customs space of Ukraine in the context of social and economic transformations becomes important. Given the political and economic situation in our country, an important component of the implementation of effective customs policy should be to determine its directions on the basis of the principles of foreign economic activity, the priorities of the strategy of economic development of the state.

Methods. General scientific techniques and methods of economic research were used in the process of writing the article. The theoretical and methodological basis of intelligence is the analysis of scientific works of domestic and foreign scientists on the study of problematic aspects of the customs space of Ukraine, Internet resources. The article uses general and special research methods, in particular: general scientific and special - to ensure the achievement of this goal; dialectical, abstract and logical methods of analysis - to substantiate theoretical positions and conclusions. Techniques for graphical display of results are used.
\end{abstract}

Results. The article systematizes the problematic aspects of the formation of the customs space of Ukraine and 
formulates recommendations on the pragmatism of their solution in modern conditions. Emphasis is placed on the need to strengthen cooperation between law enforcement and customs authorities in order to reduce the risk of the customs space of Ukraine. Customs officials are invited to undergo specialized training and pre-training conducted by the Department of Specialized Training and Cynological Support, as in the period of global transformations the world economy sets new requirements for those institutions whose employees are responsible for the security of the countrys customs space. The consequences of problematic aspects of the formation of the customs space of Ukraine are outlined.

Discussion. Further research will focus on studying the state of spatial asymmetry of the customs space of Ukraine in the context of identifying opportunities and prospects for its balancing and improving efficiency. rules.

Keywords: customs space, customs environment, customs climate, customs policy, smuggling, violation of customs

\section{References}

1. Ivashchuk, I.O. (2009). Otsinka aktyvnosti krayin u mytnomu prostori ta yiyi vplyv na formuvannya mytnoho seredovyshcha [Assessment of the activity of countries in the customs space and its impact on the formation of the customs environment]. Naukovi zapysky Natsionalnoho universytetu "Ostrozka akademiya». Seriya : Ekonomika [Scientific Notes of the National University "Ostroh Academy". Series: Economics], 11, 40-57. (in Ukr.).

2. Sayt Derzhavnoyi sluzhby statystyky Ukrayiny. Retrieved from http://www.ukrstat.gov.ua

3. Sydor, H.V., \& Kulchytska, S.M. (2019). Mytnyy prostir: suchasna interpretatsiya [Customs space: a modern interpretation]. Ekonomiko-upravlinski aspekty transformatsiyi ta innovatsiynoho rozvytku haluzevykh $i$ rehionalnykh suspilnykh system v suchasnykh umovakh : Vseukr. nauk.-prakt. internet-konf. Ivano-Frankivsk, 264266.

4. Sydor, H.V., \& Kulchytska, S.M. (2019). Mytnyy prostir Ukrayiny v umovakh hlobalizatsiyi [Customs space of Ukraine in the conditions of globalization]. Aktualni problemy sotsialno-ekonomichnykh system $v$ umovakh transformatsiynoyi ekonomiky : V Vseukr. nauk.-prakt. konf. Dnipro : NMetAU, 1, 106-108. Retrieved from https://nmetau.edu.ua/ua/mdiv/i2015/p26855

5. Sydor, H.V. (2020). Otsinyuvannya aktyvnosti krayin u mytnomu prostori [Assessing the activity of countries in the customs space]. Modernizatsiya ekonomiky Ukrayiny: osnovni tendentsiyi ta problemy : kolektyvna monohrafiya. Chortkiv : TNEU, 202-210.

6. Sydor, H.V., Andrusiv, U.Ya., \& Verbitska, I. I. (2020). Stan prostorovoyi asymetriyi mytnoho prostoru v Ukrayini [The state of spatial asymmetry of the customs space in Ukraine]. Naukovyy visnyk IFNTUNH. Seriya : "Ekonomika ta upravlinnya v naftoviy i hazoviy promyslovosti» [Scientific Bulletin IFNTUNG. Series: «Economics and Management in the Oil and Gas Industry»], 2 (22), 173-180. (in Ukr.).

7. Sydor, H.V., Andrusiv, U.Ya., \& Verbitska, I.I. Stratehichni vektory rozvytku mytnoho prostoru Ukrayiny v hlobalnomu seredovyshchi [Strategic vectors of Ukraines customs space development in the global environment]. Naukovyy visnyk IFNTUNH. Seriya : «Ekonomika ta upravlinnya v naftoviy $i$ hazoviy promyslovosti» Scientific Bulletin IFNTUNG. Series: «Economics and Management in the Oil and Gas Industry»], 1 (21), 27-34. (in Ukr.).

8. Sydor, H.V. (2020). Teoretychni aspekty stanovlennya mytnoho prostoru [Theoretical aspects of the formation of customs space]. Modernizatsiya ekonomiky: suchasni realiyi, prohnozni stsenariyi ta perspektyvy rozvytku : Mizhnar. nauk.-prakt. konf. Kherson, 563-565.

9. Stolin, V.V. (1983). Samosoznaniye lichnosti [Self-awareness of the individual]. Moskva : Izdatelstvo Moskovskogo universiteta.

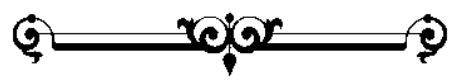

